\title{
PENGARUH PENGGANTIAN SEBAGIAN RANSUM DENGAN TEPUNG LIMBAH LABU KUNING (Cucurbita moschata) TERHADAP PERFORMANS AYAM PEDAGING
}

\author{
Julin Salauhiang, Marie Najoan*, Cherly J. Pontoh, Meity R. Imbar \\ Fakultas Peternakan Universitas Sam Ratulangi Manado, 95115
}

\begin{abstract}
ABSTRAK
Penelitian ini bertujuan untuk mengetahui sejauh mana penggantian sebagian ransum dengan tepung limbah labu kuning (Cucurbita moschata) yang diukur melalui performans ayam pedaging. Menggunakan 100 ekor ayam pedaging unsexed Strain Cobb 707 umur 1 hari dengan rataan berat badan \pm 45,32 g. Rancangan yang digunakan adalah Rancangan Acak Lengkap (RAL) yang terdiri dari 4 perlakuan dan 5 ulangan. Susunan perlakuan sebagai berikut : R0 = $100 \%$ ransum basal $(\mathrm{RB})+0 \%$ tepung limbah labu kuning (TLLK), R1 $=95 \% \mathrm{RB}$ $+5 \%$ TLLK, R $2=90 \% \mathrm{RB}+10 \%$ TLLK, $\mathrm{R} 3=85 \% \mathrm{RB}+15 \%$ TLLK. Hasil analisis keragaman menunjukkan bahwa perlakuan tidak berpengaruh nyata $(\mathrm{P}>0,05)$ terhadap konsumsi ransum, pertambahan berat badan dan konversi ransum. Penggunaan tepung limbah labu kuning dapat menggantikan sebagian ransum sampai $15 \%$.
\end{abstract}

Kata kunci :Performans, limbah labu kuning, ayam pedaging.

\section{ABSTRACT \\ EFFECT OF REPLACEMENT SOME RATIONS WITH FLOUR YELLOW PUMPKIN WASTE (CUCURBITA MOSCHATA) AGAINST PERFORMANCE \\ BROILER. This study aims to determine}

*Kosepondensi (corresponding author)

Email : Marie.Najoan@yahoo.com the extent of the partial replacement of rations with pumpkin waste flour (Cucurbita moschata) as measured by broiler performance. Using 100 unsexed broiler Cobb 707 aged 1 day with average body weight $\pm 45.32 \mathrm{~g}$. The design used was a Completely Randomized Design (CRD) consisting of 4 treatments and 5 replications. The treatment composition is as follows: $\mathrm{R} 0=100 \%$ basal ration $(\mathrm{RB})+$ $0 \%$ pumpkin waste flour (TLLK), R1 = $95 \% \mathrm{RB}+5 \%$ TLLK, R2 $=90 \% \mathrm{RB}+10 \%$ TLLK, R3 $=85 \% \mathrm{RB}+15 \%$ TLLK. Results of analysis of variance showed that the dissecting treatment was not significant $(\mathrm{P}>0.05)$ for the consumption, weight and conversion of ration The use of pumpkin waste flour can replace a portion of the ration up to $15 \%$.

Key words: Performance, waste pumpkin, broiler.

\section{PENDAHULUAN}

Usaha peternakan ayam pedaging merupakan jenis usaha pemeliharaan ternak yang mampu menyediakan kebutuhan daging dengan waktu yang relative singkat. Pertumbuhan ayam pedaging yang cepat harus diimbangi dengan ketersediaan ransum yang cukup, karena kekurangan ransum akan mengganggu laju pertumbuhan. Oleh karena itu pengadaan 
ransum harus dilakukan secara kontinu dan mencukupi kebutuhan ternak.

Ransum memegang peranan penting baik dari segi biologis maupun ekonomis, karena ransum mengandung zatzat nutrient yang dibutuhkan ternak serta biayanya merupakan terbesar mencapai $70 \%$ sehingga penggunaan bahan pakan sangat menentukan biaya produksi. Penyediaan ransum yang memadai secara kuantitas dan kualitas sangat diharapkan dalam peningkatan produktivitas ayam pedaging. Produktivitas yang baik memerlukan ransum yang bernilai nutrien yang baik pula. Bahan-bahan pakan harganya mahal, untuk itu perlu dicari bahan pakan alternatif yang murah, tidak bersaing dengan kebutuhan manusia, mudah didapat, dan mengandung zat-zat nutrien yang dibutuhkan ternak. Kebutuhan protein untuk ayam pedaging berkisar antara 18\%-24\%, sedangkan kebutuhan energi metabolis sebesar 2900-3400 $\mathrm{kkal} / \mathrm{kg}$ (Wahyu, 2004).

Limbah labu kuning merupakan salah satu limbah yang cukup banyak ditemui di daerah Sulawesi Utara. Ketersediaan limbah labu kuning meningkat dengan meningkatnya konsumsi masyarakat terhadap hasil olahan berbagai jenis makanan dari buah labu kuning. Tingkat produksi labu kuning di Indonesia relatif tinggi, dan produksinya dari tahun ke tahun terus meningkat yaitu 428.197 ton (2011) dan meningkat 523.063 ton (2014) (Badan Pusat Statistik 2014).

Komposisi nutrien limbah labu kuning per 100 gram antara lain : Protein 23,14\%, Lemak 14,59\%, Serat kasar 17,48\%, Kalsium 0,76\%, Fosfor 0,75\% (Komalig et al., 2016). Melihat komposisi nutrien limbah labu kuning, maka cukup tepat untuk dijadikan salah satu bahan pakan alternatif penyusun ransum ayam pedaging. Penggunaan limbah labu kuning sebagai bahan pakan berarti juga telah membantu mengatasi limbah organik dan sekaligus memberikan solusi dalam mengatasi mahalnya pakan komersial.

\section{MATERI DAN METODE PENELITIAN}

Penelitian ini dilaksanakan di Kandang Unggas, Fakultas Peternakan Universitas Sam Ratulangi Manado. Waktu pelaksanaan pada tanggal 7 Agustus - 10 September 2018 (5 Minggu). Penelitian ini sebanyak 100 ekor ayam pedaging unsexed strain cobb 707 umur 1 hari dengan rataan berat badan $\pm 45,32 \mathrm{~g}$. Kandang yang digunakan dalam penelitian ini adalah kandang sistem battery terbuat dari kawat dengan ukuran $60 \times 45$ x $45 \mathrm{~cm}$ sebanyak 20 unit, tiap unit kandang ditempatkan 5 ekor ayam. Kandang tersebut ditempatkan 
dalam ruangan dengan ventilasi dan cahaya

yang cukup. Perlengkapan yang digunakan

Tabel 1. Komposisi Nutrien Bahan Pakan Penyusun Ransum

\begin{tabular}{lcccccc}
\hline Bahan Makanan & Protein & Serat Kasar & Lemak & Ca & P & EB \\
& $\%$ & $\%$ & $\%$ & $\%$ & $\%$ & Kcal/kg \\
\hline Jagung* & 8,01 & 4,45 & 7,71 & 0,17 & 0,7 & 3821 \\
Tepung Kedelai* & 42,02 & 6,4 & 13,22 & 0,21 & 0,65 & 4804 \\
Tepung Ikan* & 63,6 & 0,5 & 9,3 & 5,81 & 3,23 & 2830 \\
Bungkil Kelapa* & 20,55 & 15,88 & 15,07 & 0,21 & 0,49 & 4966 \\
Dedak Halus* & 8,36 & 16,53 & 6,58 & 0,18 & 0,84 & 3419 \\
Minyak* & - & - & 100 & - & - & 8812 \\
Top Mix* & - & - & - & 5,38 & 1,44 & - \\
Limbah Labu Kuning** & 23,14 & 17,48 & 14,59 & 0,76 & 0,75 & 3882,4 \\
\hline
\end{tabular}

Sumber: * Salombre, et al., (2018)

** Komalig, et al., (2016)

Tabel 2. Komposisi Ransum Basal

\begin{tabular}{lccccccc}
\hline Bahan Makanan & Penggunaan & Protein & Serat Kasar & Lemak & Ca & P & EB \\
& $\%$ & $\%$ & $\%$ & $\%$ & $\%$ & $\%$ & Kcal/kg \\
\hline Jagung* & 45 & 3,60 & 1,55 & 3,47 & 0,08 & 0,32 & 1719,45 \\
Tepung Kedelai* & 14 & 5,88 & 0,90 & 1,85 & 0,03 & 0,09 & 672,56 \\
Tepung Ikan* & 14 & 8,90 & 0,07 & 1,30 & 0,81 & 0,45 & 396.2 \\
Bungkil Kelapa* & 11 & 2,26 & 1,75 & 1,66 & 0,02 & 0,05 & 546,26 \\
Dedak Halus* & 14 & 1,17 & 2,31 & 0,92 & 0,03 & 0,12 & 478,66 \\
Minyak* & 1 & - & - & 1,00 & - & - & 88,12 \\
Top Mix* & 1 & - & - & - & 0,05 & 0,01 & - \\
\hline
\end{tabular}

Keterangan: Dihitung berdasarkan Tabel 1

Tabel 3. Komposisi Nutrien dan Energi Bruto Ransum Perlakuan

\begin{tabular}{lcccc}
\hline Perlakuan & R0 & R1 & R2 & R3 \\
\hline Ransum Basal & 100 & 95 & 90 & 85 \\
Limbah Labu Kuning & 0 & 5 & 10 & 15 \\
\hline Zat Nutrien/Energi & & & & \\
\hline Protein (\%) & 21,82 & 21,89 & 21,95 & 22,02 \\
Serat Kasar (\%) & 6,58 & 7,13 & 7,67 & 8,22 \\
Lemak (\%) & 10,20 & 10,42 & 10,64 & 10,86 \\
Ca (\%) & 1,02 & 1,01 & 0,99 & 0,98 \\
P (\%) & 1,04 & 1,03 & 1,01 & 1,00 \\
EB (Kcal/kg) & 3901,25 & 3900,31 & 3899,37 & 3898,42 \\
\hline
\end{tabular}

Keterangan : Dihitung berdasarkan Tabel 1 dan Tabel 2 
yaitu tempat pakan, tempat air minum, wadah pencampur pakan, timbangan, kantong plastik, penampung pakan perlakuan, kipas angin, koran bekas, dan lampu. Timbangan digital untuk menimbang ayam, kantong plastik untuk tempat pakan perlakuan, alat tulis menulis untuk mencatat data berat badan ayam dan pakan sisa, serta alat kebersihan.

Komposisi Nutrien Bahan Pakan Penyusun Ransum dapat dilihat pada Tabel 1, Komposisi Ransum Basal dilihat Tabel 2 serta Komposisi Nutrien dan Energi Bruto Ransum Perlakuan dilihat pada Tabel 3. Peneltian ini merupakan penelitian eksperimental dengan menggunakan Rancangan Acak Lengkap (Steel and Torrie, 1995) yang terdiri dari 4 perlakuan dan 5 ulangan. Susunan perlakuan adalah sebagai berikut :

$\mathrm{R}_{0}=$ Ransum Basal 100\% (Tanpa Tepung Limbah Labu Kuning)

$\mathrm{R}_{1}=$ Ransum Basal 95\% + Tepung

LimbahLabu Kuning 5\%

R2= Ransum Basal 90\% + Tepung Limbah

Labu Kuning 10\%

$\mathrm{R}_{3}=$ Ransum Basal 85\% + Tepung Limbah

Labu Kuning $15 \%$.

Variabel yang diukur pada penelitian ini meliputi:

1.Konsumsi Ransum (gram), diperoleh dari jumlah ransum yang diberikan (g/ekor/hari) dikurangi dengan jumlah ransum tersisa (g/ekor/hari) pada setiap unit kandang dan diakumulasikan pada akhir penelitian.

\section{Pertambahan Berat Badan (gram).}

Pertambahan berat badan diperoleh berdasarkan selisih dari penimbangan berat badan akhir dikurangi dengan berat badan awal selama penelitian.

3.Konversi Pakan, dihitung berdasarkan perbandingan antara jumlah rataan konsumsi ransum dengan rataan pertambahan berat badan selama periode penelitian.

\section{HASIL DAN PEMBAHASAN}

Rataan Konsumsi Ransum, Pertambahan Berat Badan dan Konversi Ransum ayam pedaging yang menggunakan tepung limbah labu kuning disajikan pada Tabel 4.

\section{Pengaruh Perlakuan Terhadap Konsumsi Ransum}

Rataan konsumsi per gram per ekor per hari selama penelitian dapat dilihat pada Tabel 4 dengan rataan R0 (70,02 g), R1 $(68,77 \mathrm{~g})$, R2 (69,39 g), dan R3 (69,99 g). Kisaran rataan konsumsi ransum pada penelitian ini lebih rendah dibandingkan dengan hasil penelitian (Manalip et al., 2018) konsumsinya berkisar antara $87,05-$ 
87,73 g. Analisis keragaman menunjukkan bahwa penggunaan tepung limbah labu kuning memberikan pengaruh tidak nyata

Tabel 4. Rataan Konsumsi Ransum, Pertambahan Berat Badan dan Konversi Ransum Perlakuan

\begin{tabular}{lcccc}
\hline \multirow{2}{*}{ Parameter } & \multicolumn{4}{c}{ Perlakuan } \\
\cline { 2 - 5 } & R0 & R1 & R2 & R3 \\
\hline Konsumsi Ransum (g/ekor/hari) & 70,02 & 68,77 & 69,39 & 69,99 \\
PBB (g/ekor/hari) & 30,34 & 27,71 & 30,89 & 28,73 \\
Konversi Ransum & 2,31 & 2,51 & 2,25 & 2,47 \\
\hline
\end{tabular}

$(\mathrm{P}>0,05)$ terhadap konsumsi ransum. Hal ini disebabkan limbah labu kuning mengandung nutrien yang hampir sama dengan kandungan nutrien ransum kontrol sehingga ransum yang dikonsumsi memenuhi hidup pokok untuk ayam pedaging.

Hal ini sejalan dengan pendapat Fajri (2012) bahwa ternak unggas membutuhkan nutrien berupa protein sebagai zat pembangun tubuh, karbohidrat dan lemak sebagai sumber energi serta vitamin dan mineral yang penting bagi perkembangan tubuh.

\section{Pengaruh Perlakuan Terhadap Pertambahan Berat Badan}

Rataan pertambahan berat badan per ekor per hari selama penelitian dapat dilihat pada Tabel 4 masing-masing perlakuan yaitu R0 (30,34 g), R1 (27,71 g), R2 (30,89 g) dan R3 (28,73 g). Analisis keragaman menunjukkan bahwa penggunaan tepung limbah labu kuning tidak berpengaruh nyata $(\mathrm{P}>0,05)$ terhadap pertambahan berat badan ayam pedaging. Penggantian ransum dengan tepung limbah labu kuning sampai $15 \%$ memberikan pertambahan berat badan yang sama. Menurut Praptiwi dan Indriastuti (2015), bahwa pertumbuhan ternak berbanding lurus dengan konsumsi ransum semakin tinggi berat badan semakin tinggi pula tingkat konsumsi ransum. Pertambahan berat badan sangat berkaitan dengan konsumsi ransum, apabila konsumsi ransum terganggu maka akan mengganggu pertumbuhan (Uzer et al., 2013). 
Rendahnya pertambahan berat badan pada penelitian ini disebabkan rendahnya ransum yang dikonsumsi ternak, dimana semakin rendah konsumsi menyebabkan rendahnya nutrien yang masuk dalam tubuh ternak sehingga kebutuhan untuk pertumbuhan tidak terpenuhi (Murib et al., 2016).

\section{Pengaruh Perlakuan Terhadap Konversi Ransum}

Data rataan konversi ransum dalam penelitian ini dapat dilihat pada Tabel 4 masing-masing perlakuan yaitu R0 (2,31), R1 (2,51), R2 (2,25) dan R3 (2,47). Nilai konversi ransum dalam penelitian ini lebih rendah dibandingkan dengan penelitian yang dilaporkan Djapili et al. (2016), yaitu berkisar antara 2,62-3,09 per ekor per hari.

Analisis keragaman menunjukkan bahwa penggunaan tepung limbah labu kuning tidak berpengaruh nyata $(\mathrm{P}>0,05)$ terhadap konversi ransum. Rata-rata konsumsi ransum dan pertambahan bobot badan pada penelitian ini memberikan pengaruh yang berbeda tidak nyata. Semakin tinggi angka konversi ransum menunjukkan tingkat efisiensi ransum yang rendah, sebaliknya semakin rendah angka konversi ransum menunjukkan tingkat efisiensi lebih tinggi (Allama et al., 2012).

Hal ini sejalan dengan pendapat Anggorodi (1994), bahwa konversi ransum sangat dipengaruhi oleh konsumsi ransum dan pertambahan bobot badan. Semakin kecil nilai konversi ransum maka semakin besar peluang bagi peternakan untuk memperoleh keuntungan, karena biaya ransum merupakan biaya terbesar dalam usaha peternakan.

\section{KESIMPULAN}

Penggunaan tepung limbah labu kuning dapat menggantikan sebagian ransum sampai $15 \%$.

\section{DAFTAR PUSTAKA}

Allama, H., O. Sofyan, E. Widodo dan H. S. Prayogi. 2012. Pengaruh penggunaan tepung ulat kandang (Alphitobius diaperinus) dalam pakan terhadap penampilan produksi ayam pedaging. J. Ilmu Peternakan. $22(3): 1-8$

Anggorodi, 1994. Ilmu Makanan Ternak Umum. Gramedia Pustaka Utama Jakarta.

BPS, 2014. Data Produksi Tanaman Semusim. Jakarta.

Djapili, D., F. Wolayan, I. Untu dan H. Liwe, (2016). Pengaruh penggantian sebagian jagung dengan tepung kulit pisang raja (Musa Paradisiaca) dalam ransum terhadap performans broiler. Zootek 36 (1) : 158 - 166

Fajri, N. 2012. Pertambahan berat badan, konsumsi dan konversi pakan broiler yang mendapat ransum 
mengandung berbagai level tepung daun katuk (Sauropus Androgynus). Skripsi. Fakultas Peternakan Universitas Hasanuddin. Makassar.

Komalig, D. F., J. R. Leke., J. Laihat dan C. Sarajar. 2016. Penggunaan tepung limbah labu kuning dalam ransum terhadap penampilan produksi ayam ras petelur. Zootek 36(2): 342-352

Manalip. O. M., M. Najoan., M. R. Imbar dan Y.H.S. Kowel 2018. Penggantian sebagian jagung dengan tepung batang pisang goroho (Musa acuminate $s p$ ) dalam ransum terhadap performans broiler. Zootek $38(2): 296-305$

Murib, S., M. Najoan, B. Bagau dan I. M. Untu. 2016. Pengaruh substitusi dedak halus dengan tepung kulit kopi dalam pakan terhadap performa broiler. Zootek 36(1):218-225.

Praptiwi I. I dan A. T. D. Indriastuti, 2015. Kualitas ayam broiler dengan pemberian daun mayana (Solenostemon scutellarioides, L.). J. Agrinimal 5(1) : 1-5

Salombre, F. J., M. Najoan., F. N. Sompie dan M. R. Imbar 2018. Pengaruh penggunaan silase kulit pisang kepok (Musa paradisiaca formatypica) sebagai pengganti sebagian jagung terhadap karkas dan viscera broiler. Zootek 38(1): 27-36.

Steel, R. G. D dan J. H. Torrie. 1995. Prinsip dan Prosedur Statistika : Suatu Pendekatan Biometrik. Terjemahan B. Sumantri. Gramedia Pustaka Utama, Jakarta.

Uzer, F., N. Iriyanti dan Roesdiyanto. 2013. Penggunaan pakan fungsional dalam ransum terhadap konsumsi pakan dan pertambahan bobot badan ayam broiler. J. Ilmiah Peternakan 1(1): 282-288.

Wahyu, J. 2004. Ilmu Nutrisi Unggas. Cetakan Kelima. Gadjah Mada University Press. Yogyakata. 